\title{
sciendo
}

\section{What matters: The Formation of University Spin-offs in Europe}

\author{
Jan Hunady, Marta Orviska, Peter Pisar \\ Faculty of Economics, Matej Bel University in Banska Bystrica, Slovakia
}

\section{Abstract}

Background: Transfer of knowledge from academia to business is one of the crucial issues for creating innovation. Creation of university spin-offs could significantly improve this transfer. Objectives: The main scientific aim is to examine the differences between universities in European countries and identify factors affecting the probability of creating the university spin-off. The paper is also focused on the differences in the specialization and financial sources of universities. Methods/Approach: We compare selected indicators for higher education institutions in European countries and examine potential determinants affecting the probability of academic spin-off formation. With respect to the main aim, the logit and probit regression analyses have been used. Results: Our results show that the creation of spin-offs is typical on the one hand for highly specialized universities or on the other hand for universities with a wide variety of study programs. They should also have an optimum number of doctoral students and have mostly less funding from tuition fees. Conclusions: Several indicators appear to play an important role in the formation of university spin-off. These indicators are the level of specialization, the share of tuition fees in the University budget, and the share of Ph.D. and foreign students.

Keywords: Universities, University Spin-off, Research, Innovation, Higher education, Europe

JEL classification: 123, M13

Paper type: Research article

Received: Dec 5, 2018

Accepted: Jan 24, 2019

Citation: Hunady, j., Orviska, M., Pisar, P. (2019), "What matters: The Formation of University Spin-offs in Europe" Business Systems Research, Vol. 10 No. 1, pp.138-152.

DOI: 10.2478/bsri-2019-0010

Acknowledgment: Acknowledgments: This research was supported by the Slovak Research and Development Agency (APVV), APVV-14-0512 "Universities and regional development". We would also like to acknowledge the help of two referees.

\section{Introduction}

Universities are one of the key elements in the creation and accumulation of knowledge in society. They create a highly skilled labor force for the business and public sector and generate new knowledge through research activities. These two functions should be linked together, which could lead to their third function 
comprising especially the effective knowledge transfer from academia and research into economic practice. This function is very important especially with respect to the human capital and securing the technological progress of the economy. Establishment of academic spin-off companies is one way of getting knowledge and technologies from a university environment into practice. University spin-offs can be narrowly defined as the firms that exploit intellectual property or patented inventions generated from university research" (Di Gregorio and Shane, 2003). However, university spin-offs usually do not use intellectual property officially owned by the university (Aldridge and Audretsch, 2011). Hence, university spin-offs are commonly characterized as new enterprises established in order to apply the academic knowledge, academic infrastructure and results gained by universities, and further successfully commercialise them (Wright et al., 2007).

Even though university spin-offs seem to be an effective way of transferring knowledge, their use is still very limited in many European countries, either by legislation or by lack of experience. Even though a spin-off is usually considered to be the founding of a new company to commercialize the results of university research, it could also be an enterprise founded by university employees or graduates.

The main aim of the paper is to identify the key characteristics of universities influencing the likelihood of establishing a university spin-off company. In the first part of the paper, we briefly review the literature sources on the establishment of academic spin-off companies and problems related to technology transfer. The second part explains the data as well as the methodology used in the analytical part of the paper. Next, we compare selected indicators for university characteristics in several European countries and examine the potential factors affecting the establishment of university spin-offs. The results are interpreted and discussed in the discussion. In the conclusions, we point out the most important results of our paper.

\section{Literature review}

Universities are supposed to be one of the driving forces of innovation processes in the country. As stated by Dunning (2002), innovation is the main driver of global economic development in general. Innovation consists of knowledge that arises as a result of scientific activities and, consequently, the ability of workers to apply it into practice (Hudec et al., 2009). With respect to that, there are several studies that came to the conclusion that the intensity of science, research, and development together with the proportion of tertiary educated people are the key factors supporting innovation performance and thus also economic development (Sterlacchini, 2008).

Universities and research institutions are parts of the innovation system. Innovation systems are in general described as networks of institutions in public and private sectors whose activities and interactions are aimed at supporting, importing and diffusing new technologies (Freeman, 1987). According to Edquist (2004), the innovation system has a significant role to play in the evolution, dissemination, and exploitation of innovation.

The traditional function of universities in innovation systems lies primarily in activities within the education and research subsystems. Thus, universities provide businesses with new knowledge gained in research and development, which is then transformed into innovation.

Another potential way how the role of universities in the innovation system could be described is through the triple helix model, which captures the potential relationships between universities, government, and industry. The quality of 
connections between these three subjects is a very important factor for developing innovation and further technological development of the economy as stated for example by Etzkowitz and Leydesdorff (2000). Of course, there are also other theoretical concepts, seeing universities as parts of the external environment affecting the innovation processes in business. Hence, in general, universities could be either seen as an important part of the innovation process or as external sources of information for innovation process (Chesbrough, 2006). However, new knowledge, which is often developed at universities, is still often not transferred into the business to a substantial extent. There is always a certain information barrier between research organizations or universities and business. In order to support this transfer, national and regional institutions need to intensify the interaction between academia and business.

Universities have a predominantly beneficial effect on the local economy in the region where they operate (Rehak et al., 2015). The most important local influences of universities can be further divided into two basic categories (Strauf and Scherer, 2008), quantitative and qualitative. The quantitative impact is the financial impact on the region in the form of a flow of goods and money between public authorities, businesses and public institutions. The qualitative aspect looks more at the benefits for the economy in terms of ecological, political and socio-cultural effects.

University spin-offs can be seen as one of the ways how the university could transform new knowledge into innovation and commercialize it. Hence, university spin-off companies are enterprises founded by university staff (or graduates) assigned to the surrounding or catchment area of that university (Strauf and Scherer, 2008). The issue of the spin-off is quite extensive and involves a wide range of elements, while a university spin-off is one of the specific types of spin-off companies (Salvador, 2011).

Cusmano et al. (2014) reported that spin-offs are one of the key elements supporting regional growth. Similarly, Strauf and Scherer (2008) consider it essential for a region's development strategy to include knowledge transfer and innovation through project collaboration. This type of business is important, in particular, to make a connection between students and businesses (e.g., to solve specific practical problems in their thesis).

The actual process of university spin-off creation is illustrated in more detail in Figure 1. The basic prerequisite for further steps is the identification of key competencies at the institutional level. Another essential element is research funding, which can be from the university itself or through external funding, whether public or private. The result of the research could be an invention or innovation. The innovation could then be patented by the university under certain conditions. The next phase is already in the competence of the technology transfer center at the university, if such a center is created there. In this stage, it is decided whether the technology will be leased to business or a new university spin-off will be created. The outcome of the whole process should generate future economic and social value for the university, business, as well as for the entire society.

The process of spin-off creation is relatively challenging for the university. Successful transformation of knowledge into innovation of usable products or services requires the acquisition of a number of new competencies. However, universities traditionally operate primarily in the non-commercial sphere (Vohora et al., 2004). To support the university's entrepreneurial competencies, it is usually crucial to create a completely new routine and leave the original educational and research-based routine (Rasmussen and Borch, 2010). The acquisition of 
entrepreneurial skills may sometimes conflict with the university's traditional education and research policies (Bercovitz and Feldman, 2008).

Van Burg et al. (2008) argue that in order to create backgrounds for future academic spin-off activities, academic institutions should improve their entrepreneurship awareness and support the creation of new entrepreneurial ideas. Moreover, learning and practice of the entrepreneurial skills and knowledge are also very necessary. This comes hand in hand with creating collaborative networks and setting up clear rules.

Figure 1

A multi-stage model of university spin-off creation

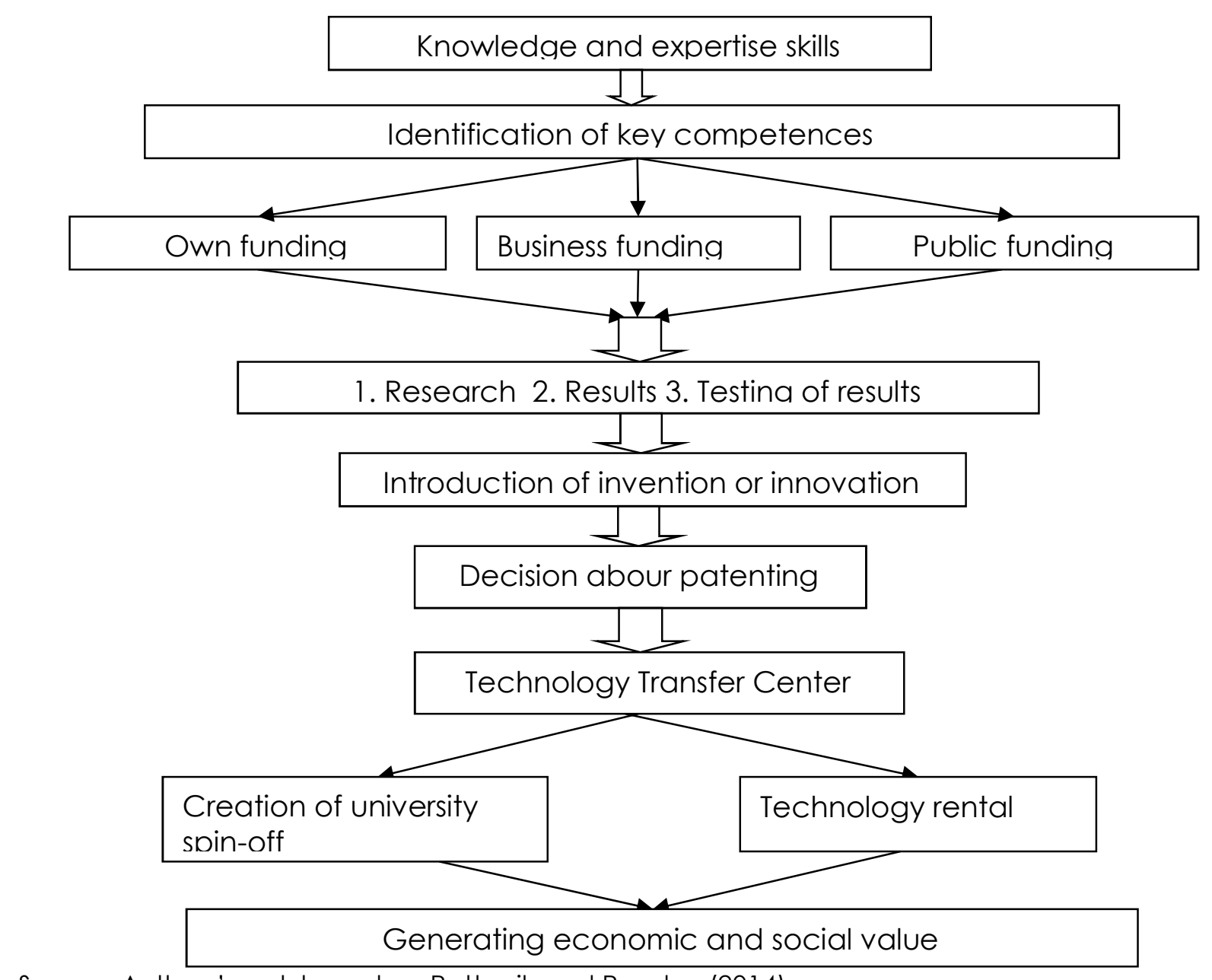

Source: Authors' work based on Pattnaik and Pandey (2014)

According to Bigliardi et al. (2013), the success of newly created projects and spin-offs depends on several factors linked to the characteristics of each university. Such factors influencing the future success of academic spin-off companies in selected studies (Bigliardi et al., 2013) can be summarized in the following four key points: (i) characteristics of the university; (ii) characteristics of the founders of the spin-off company; (iii) characteristics of the surrounding environment; and (iv) characteristics of the technology or the final product itself. In order to successfully establish the spin-off, the support for these 3 critical types of competencies is needed at the university (Rasmussen and Wright, 2015): (i) develop viable business opportunities; (ii) involve individuals in the business process and their subsequent 
active and passive support; and (iii) provide the resources needed to set up and develop an enterprise.

Thus, we can say that the characteristics of the university seem to have a significant impact on the efficiency and success of academic spin-offs (Epure et al., 2014). Furthermore, results of previous studies show that accumulated human capital and direct financial support from university strongly support the likelihood of establishing a spin-off company as well as its future success (Mustar and Wright, 2010). The legislative environment and some specific characteristics of the education system in each country could play a very important role.

This paper focuses on comparing and examining the characteristic features of universities in European countries based on available secondary data. In the next step, the focus will be on the examination of factors at the institutional level which could impact the probability of creating an academic spin-off. Hence, the paper aims to compare and examine characteristic features of higher education institutions in Europe and based on regression analysis identify factors affecting the probability of creating an academic spin-off company. We want also to mention that this paper is partially based on the results presented at Entrenova conference 2018 previously published in Hunady et al. (2018).

\section{Methodology}

In line with the main scientific aim of the paper, we analyzed available secondary data. The European Tertiary Education Register (2017) was the basic data source. This database contains data for more than 2400 institutions from 36 European countries. The data are available for 2011 (academic year 2011/2012), 2012 (academic year 2012/2013), 2013 (academic year 2013/2014) and 2014 (academic year 2014/2015). We compare the average values of selected indicators in European countries and identify the key differences. With respect to the main aim of the paper, we also focused on the factors potentially influencing the probability of university spin-off creation. Based on this scientific aim we also stated four research hypotheses as follows.

Hypothesis H01: Universities which are specialized in a few research areas are more likely to create their own spin-off company. We assume that the narrow focus of universities on selected research areas and topics allows them to improve in applied research and develop commercially useful innovations.

Hypothesis H02: Universities with a higher share of Ph.D. students are more likely to create a university spin-off. The share of Ph.D. students can be seen as the proxy for the intensity of research activities in the university. More Ph.D. students could also mean more human resources engaged in science and that can be beneficial for activities related to the spin-off.

Hypothesis H03: Universities with a higher share of foreign students are more likely to create their own academic spin-off. Universities with a higher share of foreign students are usually more open to knowledge and practices from abroad. We assume that the exchange of knowledge and experiences from abroad as well as the international focus of the institution can be beneficial for the creation of university spin-off companies.

Hypothesis H04: Universities with a lower share of tuition fees from students of overall revenues are more likely to create their own academic spin-off. This assumption is mostly related to the focus of the university either on education or on research. Universities with a higher share of revenues from student payments can be more focused on the education function and therefore less interested in creating a university spin-off. 
In the European Tertiary Education Register survey higher education institutions are supposed to indicate whether an event affecting the institution occurred in the year before or in the year following the year under review. One of these possible events is the establishment of a spin-off (or spin-out). The spin-off has to be separated from the monitored institution in selected years. Spin-out in this case means any detachment of part of a higher education institution (most often a research center or department) and the creation of a new independent intellectual property institution or technology originating from the original institution. Based on these data we further used probit regression analysis and binary logistic regression, in order to identify potential factors affecting the establishment of the spin-off.

The variables used in regression models are further specified in Table 1.

Table 1

Description of variables used in regression models

\begin{tabular}{|c|c|}
\hline Name of variables & Description of variables \\
\hline $\begin{array}{c}\text { Creation of university spin- } \\
\text { off }\end{array}$ & $\begin{array}{l}\text { Did the university spin-off occur in the reference period ?: yes } \\
\qquad \text { (coded as 1), no (coded as 0) }\end{array}$ \\
\hline $\begin{array}{l}\text { Herfindahl index of } \\
\text { concentration } \\
\text { /specialisation }\end{array}$ & $\begin{array}{l}\text { The index reflects the institution's degree of specialization } \\
\text { ranging from } 1 \text { (all students studying in the same area) to } 0 \\
\text { (even distribution of students across all fields of study). }\end{array}$ \\
\hline The intensity of Ph.D. study & Ph.D. students (their share on the total number of students) \\
\hline The share of tuition fees & The share of revenues from tuition fees on the total revenue \\
\hline $\begin{array}{l}\text { Number of Erasmus } \\
\text { students }\end{array}$ & $\begin{array}{c}\text { Number of students leaving for a foreign study stay through the } \\
\text { Erasmus program }\end{array}$ \\
\hline $\begin{array}{l}\text { The share of foreign } \\
\text { students }\end{array}$ & $\begin{array}{l}\text { The share of foreign students on the total number of students at } \\
\qquad \text { a higher education institution }\end{array}$ \\
\hline
\end{tabular}

Source: Authors' work according to data from the European Tertiary Education Register (2017).

The Herfindahl index of concentration (also known as Herfindahl-Hirschman Index) has been used in order to capture the specialization of higher education institutions with respect to different fields of study. We take into account bachelor and master study programs, but the emphasis was especially on doctoral study programs. Hence, based on this indicator we can determine the degree of specialization in research. This index captures the absolute measure of specialization and it is calculated as follows:

$$
\begin{gathered}
H I_{i}=\sum_{j=1}^{m}\left(g_{i j}^{S}\right)^{2} \\
\text { where: } g_{i j}^{S}=\frac{X_{i j}}{\sum_{j=1}^{m} X_{i j}}=\frac{X_{i j}}{X_{i}}
\end{gathered}
$$

$\mathrm{H}_{\mathrm{i}}$ - Herfindahl index of concentration or specialization,

$\mathrm{i}$ - institution; $\mathrm{j}$ - branch (study field), $X_{i}$-the number of students an the institution $\mathrm{I}$,

$X_{i j}$ - the number of students in study field $j$ in the institution $i$,

$\mathrm{g}_{\mathrm{sij}}$ - the share of study filed $\mathrm{j}$ in the $f$ institution $\mathrm{i}$

\section{Results}

As the first step, we compared selected indicators for European countries. These indicators are country averages for all higher education institutions included in the sample (European Tertiary Education Register) from each country. However, where 
an indicator was missing for some country, this country was excluded from the comparison in this indicator. We compare average Herfindahl index for Ph.D. graduates (Figure 2) in selected European countries.

Figure 2

Herfindahl index for Ph.D. graduates

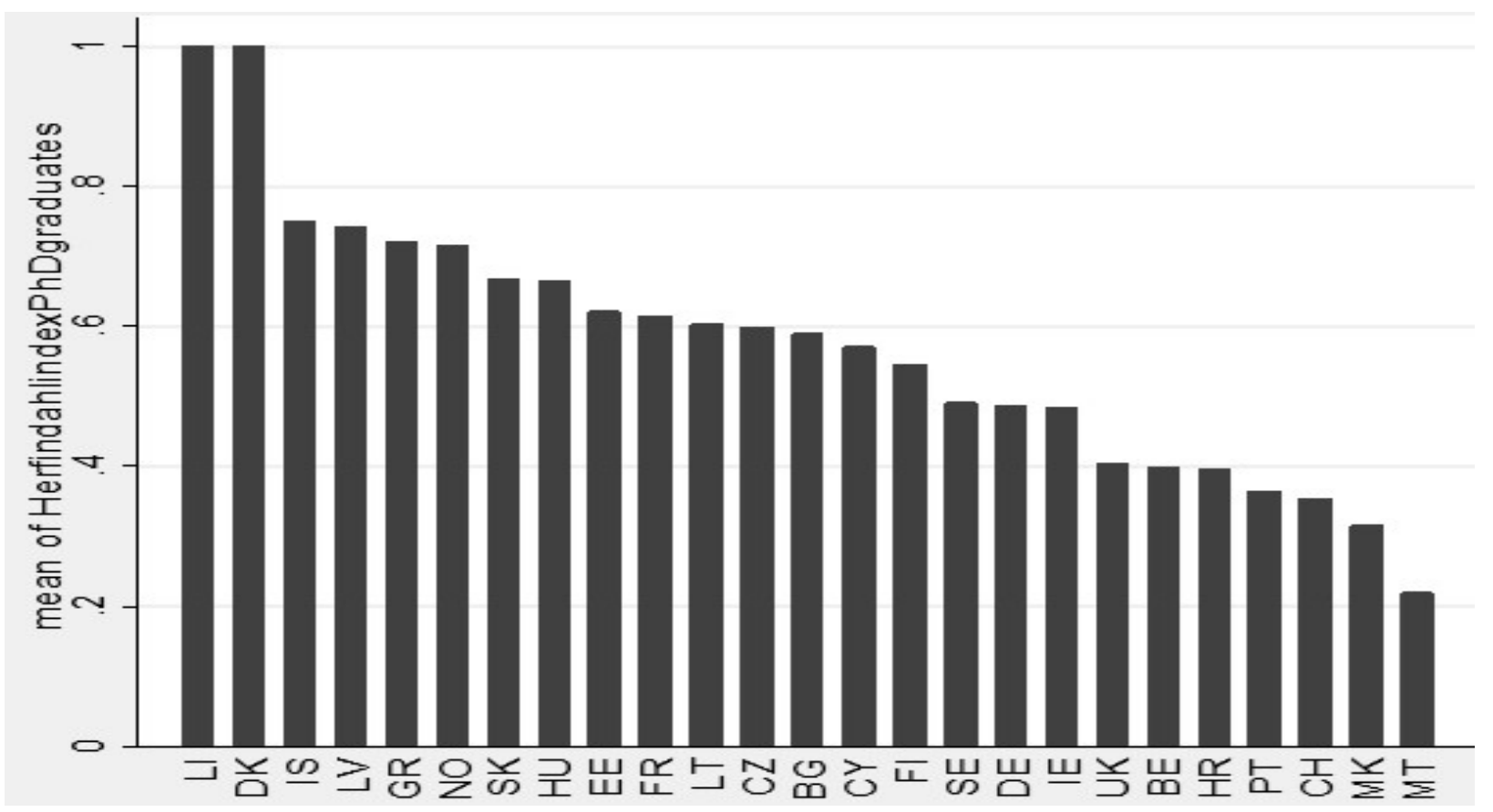

Source: Authors' work based on data from the European Tertiary Education Register (2017).

Figure 3 shows the average Herfindahl index for all ISCED students at universities in selected European countries.

Figure 3

Herfindahl index for all ISCED students at universities

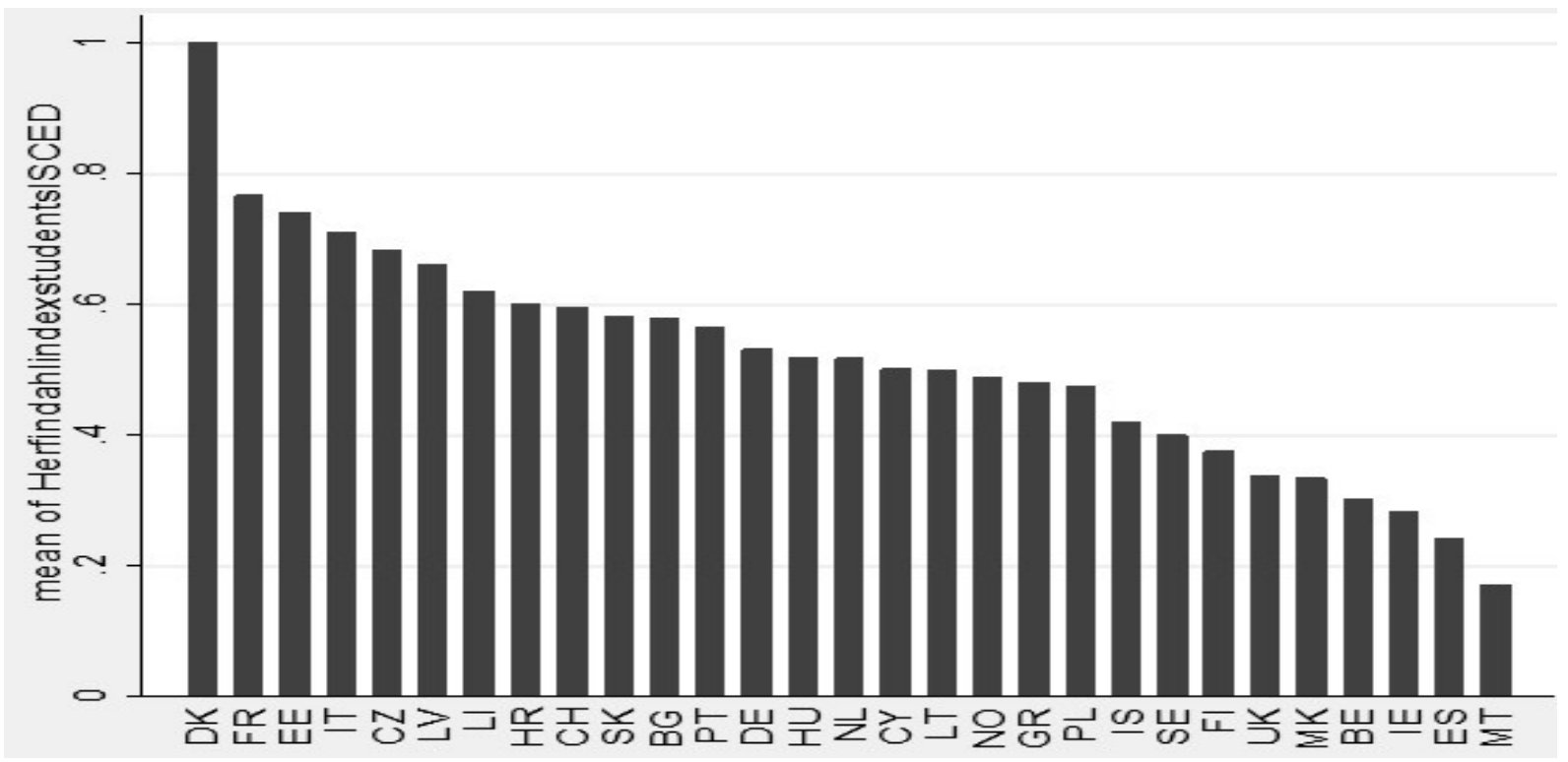

Source: Authors based on data from the European Tertiary Education Register (2017). 
The highest degree of specialization of Ph.D. study can be seen in Lichtenstein and Denmark. However, in the cases of these countries, only a small number of institutions have been included in the sample. On the other hand, Ph.D. graduates form Malta, Macedonia and Switzerland are distributed more evenly across different fields of study. Furthermore, the highest values of the Herfindahl index for all students are found in Demark, France, and Estonia, which again suggest that students are more concentrated in certain fields of study in these countries.

In the next part of the analysis, we look at different types of financial sources. Figure 4 compares the average share of third-party funding on the overall budget in different countries. This financial source seems to be the most common in Lichtenstein, Sweden, and Ireland. The higher values of this indicator could to some extent reflect the successful cooperation of universities with businesses.

Figure 4

The average share of third-party funding on the overall budget of universities

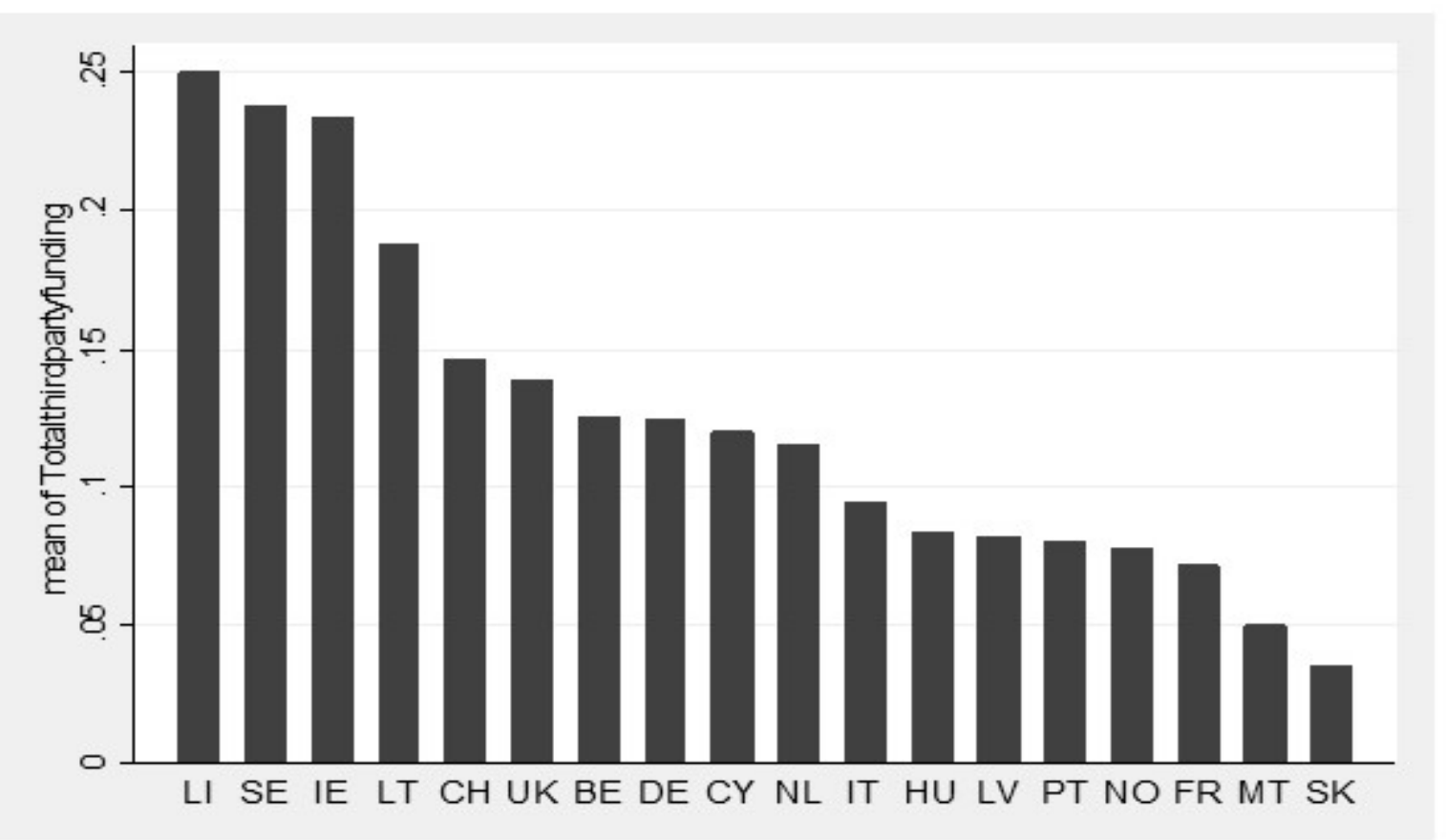

Source: Authors based on data from the European Tertiary Education Register (2017).

The shares of the other two financial sources for each higher education institution in the sample is shown in Figure 5. As shown, a higher share of student fees often means a lower share of total core budget (revenues without fees and third-party funding). On the other hand, fewer revenues from student fees are mostly compensated by a bigger core budget of the university.

Next, the focus is on the indicators related to employees of the university. The average share of academic staff on the total staff of universities is shown in Figure 6. The highest proportion of academic staff is reported in the cases of universities from Belgium, Italy, and Switzerland. On the other hand, universities from Belgium seem to have a significantly lower share of full professors on academic staff (Figure 7). The opposite is true for Russian universities which have the highest share of full professors. 
Figure 5

The share of student fees funding and the share of total core budget on current revenues for each observation (higher education institution)

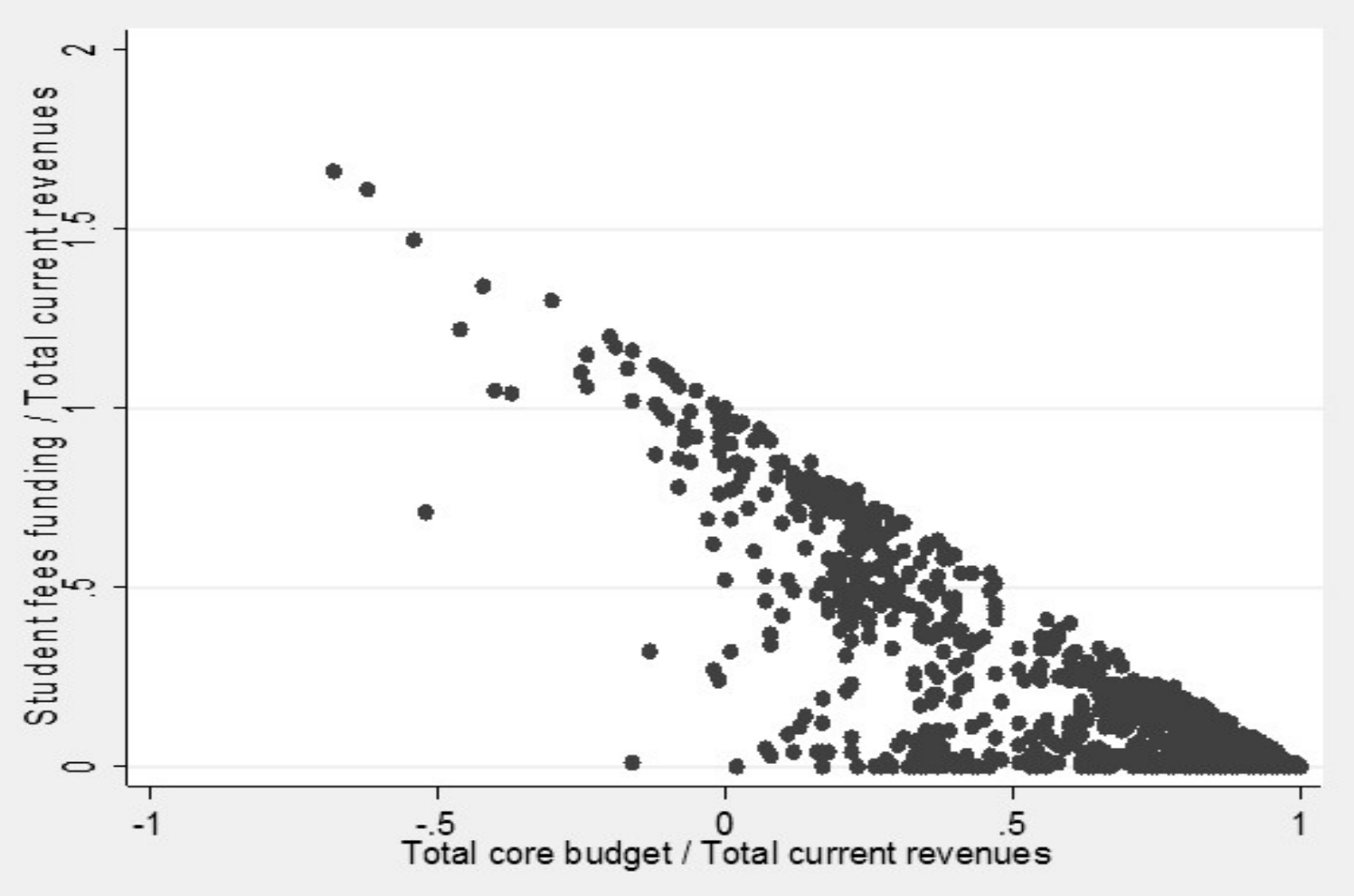

Source: Authors based on data from the European Tertiary Education Register (2017).

Figure 6

The average share of the academic staff of total university staff

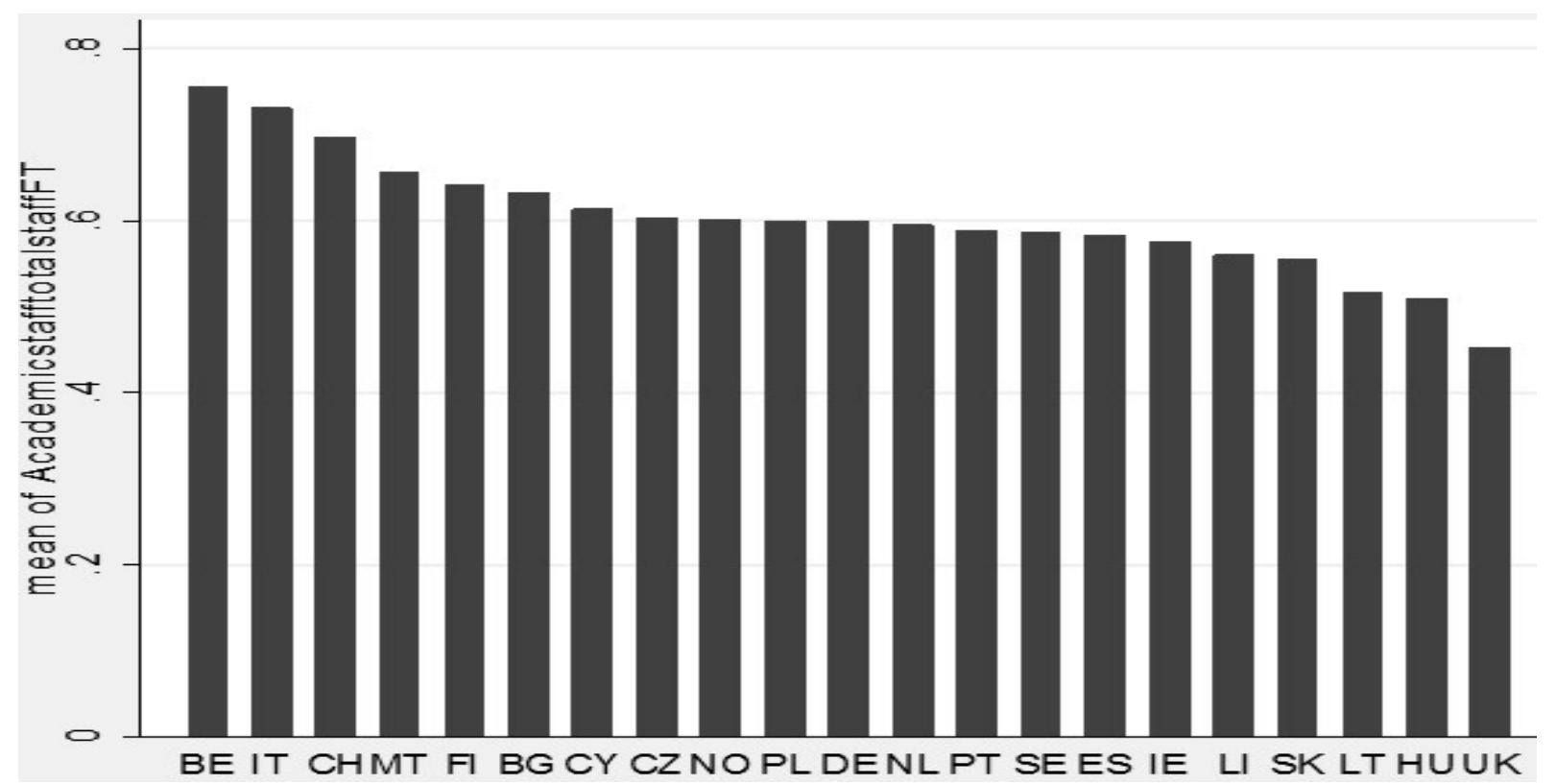

Source: Authors based on data from the European Tertiary Education Register (2017). 
Figure 7

The average share of full professors of the academic staff of universities

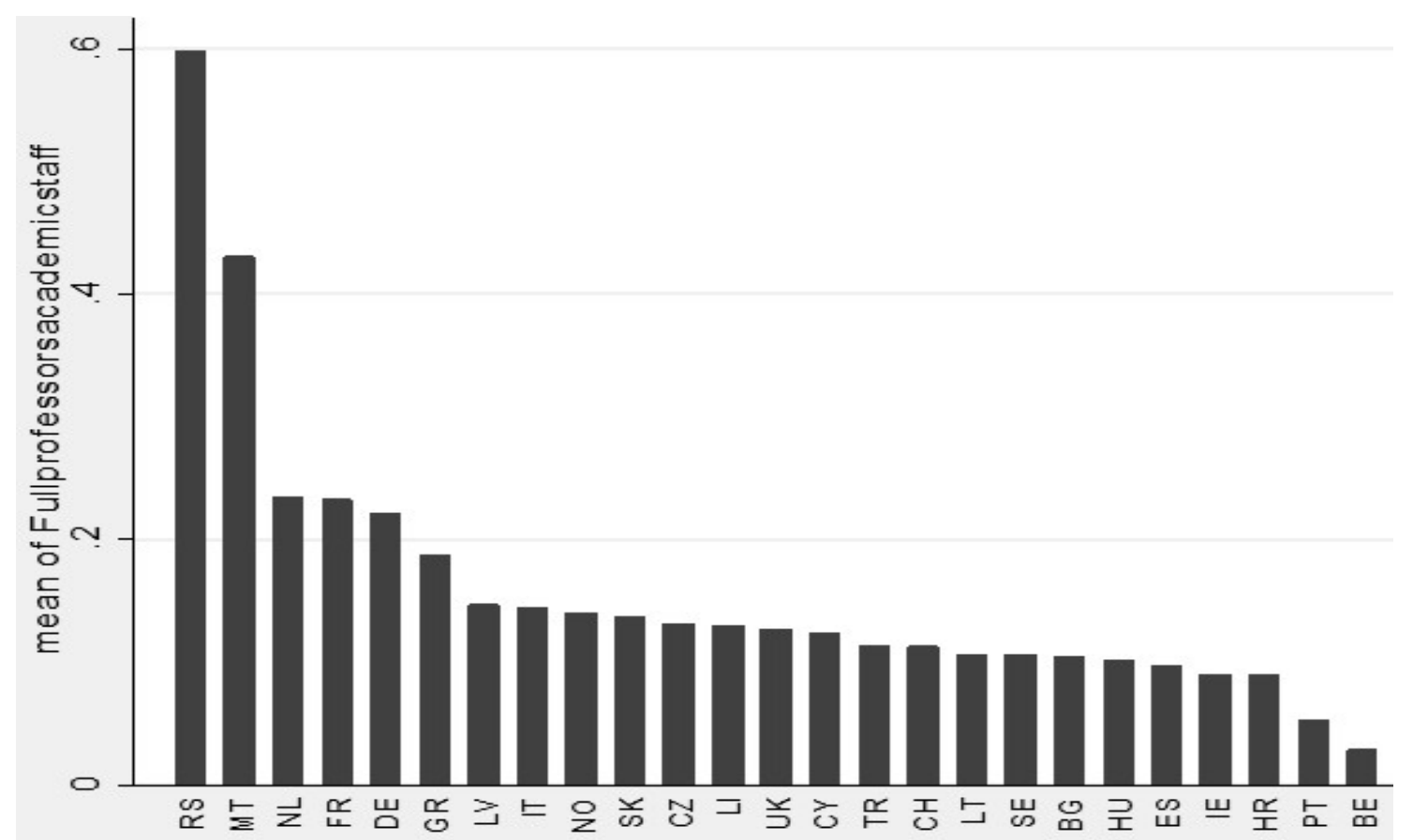

Source: Authors based on data from the European Tertiary Education Register (2017).

The potential effect of the selected variables is examined using binary logistic regression, and probit regression explained in the methodology section.

The first column shows the results of the probit regression. The results of logit regression can be seen in the second column. Another two results are based on probit regression as well. However, in this case, there are different independent variables used in each model. In the third model, we used all variables. On the contrary, in the last regression, we are focused only on Herfindahl index for Ph.D. study without taking into account the effect of other variables. This allows us to use the full sample size. The number of total observations was not restricted by data unavailability for other variables. This restriction of observations is, on the other hand, the case of the first three regression models.

Both probit and logit regression techniques were used to compare and validate the results. The Herfindahl concentration index for Ph.D. students have been used in all regressions, while in one model we also used the Herfindahl index for bachelor and master degree studies. The Herfindahl index was calculated as mentioned in the methodological section.

Moreover, three models also contain the variable capturing Ph.D. intensity.

Both mentioned variables have also been used in their squared forms. Squared values have been applied in order to capture the potential non-linear causalities. It is likely that the actual effects of specialization also depend on its initial levels. A similar situation can also be expected in the case of Ph.D. study and its intensity. In this case, we can expect that increasing the number of Ph.D. students over a certain threshold could not lead to further increase in establishing of new spin-off companies. Hence, the squared values allows us to determine potential threshold values.

The positive signs of regression coefficients by the Herfindahl index and the negative ones in the case of squared values indicate the existence of non-linear $U$ 
shape relationship. The opposite situation can be seen in the case of variable capturing the intensity of Ph.D. study, where is likely an inverse U-shape relationship. There are also positive signs of regression coefficients by several other variables - the share of foreign students and the share of university students on Erasmus. This means that these variables have a positive effect on the probability of creating an academic spin-off. On the other hand, the variable capturing the student share of tuition fees seems to have a negative effect on this probability. The effect of all mentioned variables is statistically significant at least at $5 \%$ level of significance, and most variables are significant even at $1 \%$ level.

Table 2

Results of logit and probit regression

\begin{tabular}{|c|c|c|c|c|}
\hline & (1) probit & (2) logit & (3) probit & (4) probit \\
\hline Herfindahl Index (PhD Study) & $\begin{array}{l}-6.40 * * * \\
(-5.28)\end{array}$ & $\begin{array}{l}-10.78^{* * *} \\
(-4.51)\end{array}$ & $\begin{array}{l}-7.77^{* * *} \\
(-6.59)\end{array}$ & $\begin{array}{l}-8.51^{* * *} \\
(-22.68)\end{array}$ \\
\hline Herfindahl Index²(PhD Study) & $\begin{array}{l}3.53^{* * *} \\
(3.35)\end{array}$ & $\begin{array}{l}5.29 * * \\
(2.44)\end{array}$ & $\begin{array}{l}5.89 * * * \\
(5.57)\end{array}$ & $\begin{array}{l}6.09 * * * \\
(15.65)\end{array}$ \\
\hline $\begin{array}{l}\text { Herfindahl index } \\
\text { (Bachelor and Master studies) }\end{array}$ & & & $\begin{array}{l}65.81^{* * *} \\
(3.11)\end{array}$ & \\
\hline $\begin{array}{l}\text { Herfindahl index }{ }^{2} \\
\text { (Bachelor and Master studies) }\end{array}$ & & & $\begin{array}{l}-2301.3^{* * *} \\
(-4.24)\end{array}$ & \\
\hline The intensity of Ph.D. study & $\begin{array}{l}86.76^{* * *} \\
(3.35)\end{array}$ & $\begin{array}{l}151.63^{* * *} \\
(3.19)\end{array}$ & $\begin{array}{l}65.81^{* * *} \\
(3.11)\end{array}$ & \\
\hline The intensity of Ph.D. study² & & $\begin{array}{l}-5357.7^{* * *} \\
(-4.24)\end{array}$ & $\begin{array}{l}-2301.3^{* * *} \\
(-4.24)\end{array}$ & \\
\hline The share of tuition fees & $\begin{array}{l}-4.61^{* * *} \\
(-4.20)\end{array}$ & $\begin{array}{l}-10.87^{* * *} \\
(-2.78)\end{array}$ & $\begin{array}{l}-3.60 * * * \\
(-3.33)\end{array}$ & \\
\hline Number of students on Erasmus & $\begin{array}{l}0.001^{* *} \\
(2.31)\end{array}$ & $\begin{array}{l}0.002^{* * *} \\
(2.81)\end{array}$ & $\begin{array}{l}0.001^{* *} \\
(2.28)\end{array}$ & \\
\hline Share of foreign students & $\begin{array}{l}3.07^{* * *} \\
(3.51)\end{array}$ & $\begin{array}{l}6.07^{* * *} \\
(3.53)\end{array}$ & $\begin{array}{l}3.62^{* * *} \\
(3.71)\end{array}$ & \\
\hline Akaike crit. & 0.189 & 0.185 & 0.223 & 0.238 \\
\hline Log likelihood & -110.72 & -108.45 & -109.99 & -258.12 \\
\hline Number of observations & 1247 & 1247 & 1045 & 2185 \\
\hline
\end{tabular}

Note: symbol (.) denotes $z$-statistics and $* / * / * * *$ denotes statistically significant at the $10 / 5 / 1$ percent levels. Standard errors have been corrected for heteroscedasticity.

Source: Authors' work.

The findings regarding the proposed hypotheses can be summarized as follows:

- Hypothesis H01: "Universities which are more specialized in a few research areas are more likely to create a university spin-off." We cannot reject this hypothesis. Our results support this hypothesis, but there seems to be a nonlinear relationship. This means that not only specialized institutions are more likely to create a spin-off, but also universities are lying on the other side of the specialization spectrum.

- Hypothesis H02: "Universities with a higher share of Ph.D. students are more likely to create a university spin-off". This assumption appears to be valid only partially. There is an inverted U-shape relationship between both variables. Doctoral students are necessary, but a higher share of these students does 
not necessarily mean more spin-offs. There is some optimum number of students in the middle of the spectrum.

- Hypothesis H03: "Universities with a higher share of foreign students are more likely to create a university spin-off." The results strongly suggest that a higher share of foreign students has a positive effect on the creation of university spin-offs.

- Hypothesis H04: "Universities with a lower share of tuition fees from students of overall revenues are more likely to create a university spin-off." There is also evidence that a higher share of tuition fees of total revenues can decrease the probability of creating a university spin-off.

Hence, based on the results, we can conclude that universities with very high or very low specialization are more active in creating spin-offs. Moreover, there appears to be a significant effect of other factors, in particular, Ph.D. study, the number of foreign and Erasmus students and share of tuition fees.

\section{Discussion}

The results of this study are in line with previous findings of Epure et al. (2014), who argue that university characteristics are a very important factor affecting the probability of creation of academic spin-off companies. Moreover, several other studies conclude that the characteristics of the university could play a significant role in the process of spin-off creation and determine its further success (Bigliardi et al., 2013).

Based on our results, spin-offs mostly arise from institutions that are either very narrow in their specialization or, on the other hand, broad-based and provide education in many areas. The creation of a spin-off company is not a common event for those higher education institutions which are situated somewhere between these two extremes. This is the same for the Herfindahl index of concentration at Ph.D. level as well as bachelor and master level. Thus, it is possible that higher education institutions, which are neither specialized nor big enough, have problems with creating a spin-off. This could be due to less financial power and less human capital specialised in a certain research area. Based on the comparison with the previous studies we can say that our results are complementary with findings of Mustar and Wright (2010).

On the other hand, the higher the intensity of the PhD. study the higher the probability of spin-off creation, but this is valid only to a certain threshold level. This means that the probability of establishing spin-offs gradually grows along with the increasing share of Ph.D. students up to a certain limit. Hence, the results suggest that too much, as well as too little focus on doctoral study programs is a problem with respect to the creation of spin-off companies.

Moreover, we can say that the number of students going abroad using the Erasmus program and the share of foreign students is both positively correlated with the higher probability of establishing a spin-off.

On the other hand, higher tuition fees share of revenue is a negative factor for spin-offs. This could mean that universities which are mostly oriented on education are not as active in creating spin-offs.

There are also several limitations to our research. The available secondary data allowed only the application of cross-sectional regression. Using potential panel data could improve the results especially with respect to capturing the changes over time. Furthermore, the creation of university spin-offs is a unique event. Thus, only a few universities created a spin-off directly in the selected years, but there could be more spin-offs created in the past. Our data only capture the creations of spin-offs in 
the 2011-2014 period, and we are not able to detect their actual existence. Finally, all regression models could be improved by adding more control variables. However, this is significantly limited by the availability of data.

\section{Conclusion}

Universities are seen as crucial institutions with respect to innovation development and regional economic growth. There are significant differences in their characteristics among different European countries. This is true especially for their specialization, differences in financial resources as well as the staff structure. Selected factors potentially affecting the emergence of university spin-offs have been examined on the basis of data from 2465 higher education institutions from 36 European countries.

With respect to financing, we found that the share of third-party funding has the highest share in Lichtenstein, Denmark, and Iceland. The results also suggest the fact there is a certain negative correlation between the share of tuition fees and other sources of funding. Hence, universities mostly substitute these fees with other funding sources.

The results of our regression models suggest that spin-offs are typical on the one hand for highly specialized universities, or on another hand for universities with a wide range of study programs in different study fields. Universities, which are in the middle with respect to their specialization, are usually less involved in founding a spin-off. Furthermore, a sufficient share of doctoral students is also important according to the results. However, there seems to be again a non-linear dependence between the share of Ph.D. student students and the probability of creating a spin-off company. Our results suggest that there is an optimal number of Ph.D. students required to conduct research activities and consequently maximize the probability of starting a new spin-off. At the same time, our findings confirmed that universities with a higher proportion of foreign students are more active in setting up a spin-off. This indicator may to a certain extent reflect the scope of international cooperation and networking with foreign universities in general. Interestingly, universities that usually set up spin-offs have often a relatively low share of tuition revenues from students. Despite some methodological constraints resulting from the data used, it is possible to formulate potential implications. However, it is also necessary to state that under the assumption that the establishment of spin-offs directly by universities is desirable, this should also be in line with a legislative regulation that should allow and simplify the commercialization of university research outputs. It is likely that a certain degree of support from the national or local government should also be provided for those universities willing to establish a spin-off. On the other hand, it is also necessary to recognize that spin-off companies are largely limited to the field of technology or natural sciences. The university should also have some optimal number of doctoral candidates secured. At the same time, however, it must be said that the maximum possible number of doctoral candidates usually does not maximize the probability of establishing a spin-off. From the funding point of view, it is still crucial not to rely primarily on student fee funding, as this reduces the probability of establishing an own spin-off.

\section{References}

1. Aldridge, T. T., Audretsch, D. (2011), "The Bayh-Dole act and scientist entrepreneurship", Research policy, Vol. 40, No. 8, pp.1058-1067.

2. Bercovitz, J., Feldman, M. (2008), "Academic entrepreneurs: Organizational change at the individual level", Organization Science, Vol. 19, No. 1, pp. 69-89. 
3. Bigliardi, B., Galati, F., Verbano, C. (2013), "Evaluating performance of university spin-off companies: Lessons from Italy", Journal of technology management \& innovation, Vol. 8, No. 2, pp. 178-188.

4. Chesbrough, H. W. (2006), Open innovation: The new imperative for creating and profiting from technology, Boston: Harvard Business Press.

5. Cusmano, L., Morrison, A., Pandolfo, E. (2014), "Spin-off and clustering: a return to the Marshallian district", Cambridge Journal of Economics, Vol. 39, No. 1, pp. 49-66.

6. Di Gregorio, D., Shane, S. (2003), "Why do some universities generate more start-ups than others?", Research policy, Vol. 32, No. 2, pp. 209-227.

7. Dunning, J. H. (2002), Regions, Globalization and the Knowledge Economy, London: Oxford University Press.

8. Edquist, C. (2004), "Systems of Innovation: Perspectives and Challenges", in Fagerberg, J., Mowery, D., Nelson, R. (Eds.), The Oxford Handbook of Innovation, Norfolk: Oxford University Press.

9. Epure, M., Prior, D., Serarols, C. (2016), "Assessing technology-based spin-offs from university support units", Regional Studies, Vol. 50, No. 3, pp. $411-428$.

10. Etzkowitz, H., Leydesdorff, L. (2000), "The dynamics of innovation: from National Systems and "Mode 2" to a Triple Helix of university-industry-government relations", Research policy, Vol. 29, No. 2, pp. 109-123.

11. European Tertiary Education Register (2017), ETER database, available at: https://www.eter-project.com/ (20 February 2018).

12. Freeman, C. (1987), "Technology policy and economic performance: Lessons from Japan", Research Policy, Vol.17, No. 5, pp. 309-310.

13. Hudec, O., Urbančíková, N., Džupka, P., Šebová, M., Klimovský, D., Suhányi, L., Želinský, T. (2009), Podoby regionálneho a miestneho rozvoja, Košice: Ekonomická fakulta TU.

14. Hunady, J., Orviska, M., Pisar, P. (2018), "University Characteristics as Factor Affecting the Creation of University Spin-Offs", in Proceedings of the ENTRENOVA-ENTerprise REsearch InNOVAtion Conference, Split, Croatia, Zagreb: IRENET-Society for Advancing Innovation and Research in Economy. pp. 476-484.

15. Mustar, P., Wright, M. (2010), "Convergence or path dependency in policies to foster the creation of university spin-off firms? A comparison of France and the United Kingdom", The Journal of Technology Transfer, Vol. 35, No. 1, pp. 42-65.

16. Pattnaik, P. N., Pandey, S. C. (2014), "University Spinoffs: What, Why, and How?", Technology Innovation Management Review, Vol. 4, No. 12, pp. 44-50.

17. Rasmussen, E., Borch, O. J. (2010), "University capabilities in facilitating entrepreneurship: A longitudinal study of spin-off ventures at mid-range universities", Research Policy, Vol. 39, No. 5, pp. 602-612.

18. Rasmussen, E., Wright, M. (2015), "How can universities facilitate academic spin-offs? An entrepreneurial competency perspective", The Journal of Technology Transfer, Vol. 40, No. 5, pp. 782-799.

19. Rehak, S., Dzupka, P, Sekelsky, L., Sebova, M. (2015), Lokálne ekonomické vplyvy univerzít, Bratislava: Vydavatel'stvo EKONÓM.

20. Salvador, E. (2011), "How effective are research spin-off firms in Italy?" Revue d'économie industrielle, No.133, pp. 99-122.

21. Sterlacchini, A. (2008), "R\&D, higher education and regional growth: Uneven linkages among European regions", Research Policy, Vol. 37, No. 6, pp. 1096-1 107.

22. Strauf, S., Scherer, R. (2008), "Universities and their contribution to regional development", Transformations in Business \& Economics, Vol. 7, No. 1, pp. 137-151.

23. Van Burg, E., Romme, A. G. L., Gilsing, V. A., Reymen, I. M. (2008), "Creating university spinoffs: a science-based design perspective", Journal of Product Innovation Management, Vol. 25, No. 2, 114-128.

24. Vohora, A., Wright, M., Lockett, A. (2004), "Critical junctures in the development of university high-tech spinout companies", Research policy, Vol. 33, No. 1, pp. 147-175.

25. Wright, M., Clarysse, B., Mustar, P., Lockett, A. (2007), Academic Entrepreneurship in Europe, Cheltenham: Edward Elgar. 


\section{About the authors}

Jan Hunady, PhD. is an assistant professor at the Faculty of Economics, Matej Bel University in Banska Bystrica, Slovakia. He received his Ph.D. in public economics and services at Matej Bel University. He has published a number of papers in journals such as Economia Politica, International Journal of Social Robotics, Engineering economics, and Prague Economic Papers. His research interests are focused on public finance, public sector institutions, innovation, and new technology. He also participates in several national and international projects in the area of research policy and innovation. His expertise is also in econometrics and econometrics programs, particularly panel data and time series analysis. The author can be contacted at jan.hunady@umb.sk.

prof. Ing. Marta Orviska, PhD. is a professor of finance, banking, and investment at Matej Bel University. She is one of the most cited economists in Slovakia. Her research interests are focused on macroeconomics and public finance, including tax policy and tax evasion, standardization and the analysis of attitudes to, for example, NATO and the EU in the new applicant countries and new members of the EU, and to new technologies. Since 2000, she has held several positions in national and international projects in these areas, and she has published a number of articles, including in the European Journal of Political Economy, Journal of Common Market Studies, Social Indicators Research, Journal of Policy Modeling, International Journal of Social Robotics and Nano Today. The author can be contacted at marta.orviska@umb.sk.

doc. Ing. Peter Pisar, PhD. is an associate professor of finance, banking, and investment at Matej Bel University. He has been the Head of Department of Finance and Accounting since 2015. His research is focused on European public finances, especially innovation, innovative financing and the evaluation of regional policy and public expenditure programs. In practice, he is also a consultant for the development and implementation of projects supported by EU funds and is particularly concerned with public policies supporting innovation. The author can be contacted at peter.pisar@umb.sk. 